\title{
An Overview of ARL Directors, 1933-1973
}

\begin{abstract}
This study presents a description for the period 1933-1973 of directors of U.S. academic libraries that are members of the Association of Research Libraries, comparing earlier and present directors in terms of academic preparation, age, sex, and destination upon leaving a directorship.
\end{abstract}

$\mathrm{O}_{\mathrm{s}}$

F THE SEVENTY-FOUR U.S. ACADEMIC LIBRARIES that were members of the Association of Research Libraries (ARL) in 1973, thirty-four named a new director during the four-year period January 1970 to December 1973. Two of these institutions even named a second new director within the same time period. Understandably, librarians have been much concerned over such an apparently rapid turnover in leadership at our largest and most prestigious academic libraries. The many articles and panels called together to discuss this happening have been mostly on the subject of possible changes in academic librarianship itself that might be leading more individuals to leave positions of administration.

Not much attention, however, has been placed on the nature of the new directors. Do they really represent changes in the field, or are they simply new names for the same type of persons? For that matter, are those who leave the field departing for different reasons than those who left in earlier periods? By looking at such characteristics as age on entering the field, age on becoming a director, degrees on entering the field, and degrees upon becoming a director, it should be possible to distinguish any background difference in the former

William L. Cohn is assistant professor, School of Library Science, University of Wisconsin-Milwaukee. and the incumbent directors of the ARL libraries. By looking at where the ex-directors went over the last forty years, it should be possible to see whether the destinations have become different.

Since the ARL was founded in 1932, it should be possible to take the seventyfour member libraries of 1973 (there were forty-three in 1933, but that smaller group wouldn't show the complete picture as well) as they were in 1933, as they were on a composite basis for 1934-1969, and as they have been during the discussion area of 1970-1973, and see whether there have been significant changes in background requirements for directors appointed, or significant changes in immediate locations for those who left ARL directorships in earlier times and for those who left to make way for the incumbents.

It is possible to identify 254 individuals who have served as directors during the total time span of 1933-1973 at the seventy-four libraries (this figure excludes nonacademic libraries, such as the New York Public Library, and the Canadian academic members). This total includes twenty-one individuals who served at two of the ARL libraries, and one individual who served as acting director for thirty-one years (although other acting directors could be identified, they have not been included on the 
assumption that different criteria might well be applied to the appointments of acting directors and directors).

The twenty-one two-time appointees (including ten incumbents) will be treated in terms of their first appointment for all tables concerned with the total group. This will cause some unavoidable problems with the figures on some tables, but not to any apparently harmful degree. Some tables will also show less than full numbers, because data were not fully available on all 254 individuals for all of the categories, even when the existing biographical directories were supplemented by letters of inquiry to the libraries involved. While it is possible to draw fairly significant conclusions about a group of 254 , it is not always possible in a group of seventy-four, and it is seldom possible in the still smaller subgroups in the study. Conclusions drawn, therefore, may not reflect true significance in statistical terms.

Since this study is of a descriptive nature only, no attempt has been made to determine motivation. Why persons enter the field, make position changes within it, or choose to leave it will be left for other studies. Particularly in terms of the reasons for leaving, true accounts are often hard to determine. But the destination can tell us muchdeath or retirement are obvious and unchanging reasons for leaving, and accepting a directorship at another library can hardly be construed as dissatisfaction with academic administration. Thus, knowing such factors as how many used to go into teaching or into other non-library fields and how many are currently doing so does tell a significant story.

\section{Academic Preparation of DiRECTORS}

Examination of the descriptive statistics did not lead to some of the anticipated findings. ARL directors are not showing any dramatic increases in doctorates held in the light of the very large increases in our contemporaries with the D.L.S. (used in this study for all doctorates in library science). The number of directors without libraryschool education is not decreasing. While age at appointment to director is going up, it appears to be in response to a requirement for more experience rather than more education on the doctoral level. There does seem to be a little increase in holders of two master's degrees.

Tables 1, 2, 3, and 4 give information, first, on degrees held on entrance into the profession and, second, at time of appointment to a directorship, for the total group and for the incumbents.

It was possible to become a "professional" librarian in 1933 without any college degree. It was still possible, but apparently much less probable, during the 1934-1969 period, and it wasn't done by any of the incumbents. It was very easy to become a "professional" in 1933 without benefit of library school training, and some forty-four individuals did so (over 60 percent). During 19341969 , it was still apparently easy, with sixty-two doing it (over 40 percent), but at least more were holding higher degrees in the professions or in academic subjects. Those for the 1970-1973 period (mostly incumbents, of course) involved ten individuals (almost 30 percent), with a lower percentage of higher degrees included.

By the time of appointment to a directorship (frequently the same time as entrance to the profession, particularly for those without L.S. training), the directors of 1933 still were without L.S. schooling in forty-two cases (still over 60 percent). The group for 1934-1969, however, added some L.S. degree or certificate in twenty cases, to bring the number without it down to less than 30 percent, instead of the over 40 percent who had entered the field. Almost all of 
TABLE 1

Degree (s) Held at Time of First Professional Position for Those APPOINTED BY 1933, IN 1934-1969, AND IN 1970-1973

\begin{tabular}{|c|c|c|c|c|c|c|c|c|}
\hline Name of Degree $(s)^{\circ}$ & By 1933 & Percent & $1934-1969$ & Percent & $1970-1973$ & Percent & Total & Percent \\
\hline No degrees & 6 & 8.7 & 1 & 0.7 & 0 & 0 & 7 & 2.8 \\
\hline B.A. only & 22 & 31.9 & 20 & 13.7 & 5 & 14.7 & 47 & 18.9 \\
\hline B.A. + M.A. & 7 & 10.1 & 12 & 8.2 & 2 & 5.9 & 21 & 8.5 \\
\hline Ph.D. & 8 & 11.6 & 21 & 14.4 & 3 & 8.8 & 32 & 12.9 \\
\hline \multicolumn{9}{|l|}{$\operatorname{Degree}(s)+$ Law $/$} \\
\hline Divinity & 1 & 1.5 & 8 & 5.5 & 0 & 0 & 9 & 3.6 \\
\hline B.L.S. only & 2 & 2.9 & 1 & 0.7 & 1 & 2.9 & 4 & 1.6 \\
\hline \multicolumn{9}{|l|}{ B.A. + B.L.S. or } \\
\hline Certificate & 16 & 23.1 & 36 & 24.7 & 4 & 11.8 & 56 & 22.5 \\
\hline B.A.+ M.L.S. & 0 & 0 & 14 & 9.6 & 12 & 35.3 & 26 & 10.4 \\
\hline M.A. + L.S. & 6 & 8.7 & 16 & 11.0 & 4 & 11.8 & 26 & 10.4 \\
\hline Ph.D. + L.S. & 0 & 0 & 8 & 5.5 & 2 & 5.9 & 10 & 4.0 \\
\hline B.A. + B.L.S. + M.L.S. & 0 & 0 & 5 & 3.4 & 0 & 0 & 5 & 2.0 \\
\hline B.A. + L.S. + Divinity & 1 & 1.5 & 0 & 0 & 0 & 0 & 1 & 0.4 \\
\hline B.A. + L.S. + D.L.S. & 0 & 0 & 2 & 1.3 & 1 & 2.9 & 3 & 1.2 \\
\hline M.A. + L.S. + D.L.S. & 0 & 0 & 2 & 1.3 & 0 & 0 & 2 & 0.8 \\
\hline Total & 69 & & 146 & & 34 & & 249 & \\
\hline
\end{tabular}

- All non-library science degrees are listed as B.A., M.A., and Ph.D. as appropriate. All library science master's and doctorates are listed as M.L.S. and D.L.S. respectively.

No degree information could be obtained for five of the individuals at entrance.

the change, it should be noted, came in the form of those entering the field with only a B.A. adding a library degree before becoming a director. For the 1970-1973 category, only four of the ten who entered the field without library degrees were still without them at the time of appointment to a directorship.

At the same time, those who entered the field with some L.S. degree also im- proved their educational background during each period. Twice as many 1933 directors had the M.A. + L.S. degree at appointment as had had it at entrance. The middle group showed great increases in M.A. + L.S. certificate and Ph.D. + L.S. degree, as well as in B.A. + B.L.S. + M.L.S. As a quick look at this historical period would suggest, the B.L.S. was starting to give way to the

TABLE 2

Degree(s) Held by 1973 Incumbents at First Postrion (Blank Categories from Table 1 Are Omttted)

\begin{tabular}{lrrrrrr}
\hline \hline \multicolumn{1}{c}{ Name of Degree(s) } & 1934-1969 & Percent & 1970-1973 & Percent & Total & Percent \\
\hline B.A. only & 6 & 16.7 & 7 & 18.4 & 13 & 17.5 \\
B.A. + M.A. & 3 & 8.3 & 1 & 2.6 & 4 & 5.4 \\
Ph.D. & 3 & 8.3 & 1 & 2.6 & 4 & 5.4 \\
B.A. + Law/Divinity & 1 & 2.8 & 0 & 0 & 1 & 1.4 \\
B.L.S. only & 1 & 2.8 & 1 & 2.6 & 2 & 2.7 \\
B.A. + B.L.S. or Certificate & 8 & 22.3 & 2 & 5.3 & 10 & 13.5 \\
B.A. + M.L.S. & 7 & 19.4 & 16 & 42.1 & 23 & 31.1 \\
M.A. + L.S. & 3 & 8.3 & 5 & 13.2 & 8 & 10.8 \\
Ph.D. + L.S. & 3 & 8.3 & 2 & 5.3 & 5 & 6.7 \\
B.A. + B.L.S. + M.L.S. & 1 & 2.8 & 0 & 0 & 1 & 1.4 \\
B.A. + L.S. + Divinity & 0 & 0 & 2 & 5.3 & 2 & 2.7 \\
B.A. + L.S. + D.L.S. & 0 & 0 & 1 & 2.6 & 1 & 1.4 \\
$\quad$ Total & 36 & & 38 & & 74 & \\
\hline
\end{tabular}

- All non-library science degrees are listed as B.A., M.A., and Ph.D. as appropriate. All library science master's and doctorates are listed as M.L.S. and D.L.S. respectively. 
TABLE 3

Degree(s) Held at Trme of Appointment to an ARL Directorship BY 1933, IN 1934-1969, AND IN 1970-1973

\begin{tabular}{|c|c|c|c|c|c|c|c|c|}
\hline Name of Degree $(s)^{\bullet}$ & By 1933 & Percent & 1934-1969 & Percent & $1970-1973$ & Percent & Total & Percent \\
\hline No degrees & 6 & 8.8 & 2 & 1.4 & 0 & 0 & 8 & 3.2 \\
\hline B.A. only & 16 & 23.5 & 2 & 1.4 & 0 & 0 & 18 & 7.2 \\
\hline B.A. + M.A. & 10 & 14.7 & 7 & 4.8 & 1 & 2.7 & 18 & 7.2 \\
\hline Ph.D. & 7 & 10.3 & 24 & 16.5 & 3. & 8.1 & 34 & 13.6 \\
\hline \multicolumn{9}{|l|}{ Degree(s) + Law/ } \\
\hline Divinity & 3 & 4.5 & 7 & 4.8 & 0 & 0 & 10 & 4.0 \\
\hline B.L.S. only & 0 & 0 & 0 & 0 & 1 & 2.7 & 1 & 0.4 \\
\hline \multicolumn{9}{|l|}{ B.A. + B.L.S. or } \\
\hline Certificate & 15 & 22.0 & 12 & 8.3 & 2 & 5.4 & 29 & 11.6 \\
\hline B.A.+ M.L.S. & 1 & 1.5 & 14 & 9.7 & 16 & 43.3 & 31 & 12.4 \\
\hline M.A. + L.S. & 10 & 14.7 & 19 & 13.1 & 4 & 10.8 & 33 & 13.2 \\
\hline Ph.D. + L.S. & 0 & 0 & 16 & 11.0 & 5 & 13.5 & 21 & 8.4 \\
\hline B.A. + B.L.S. + M.L.S. & 0 & 0 & 16 & 11.0 & 1 & 2.7 & 17 & 6.8 \\
\hline B.A. + L.S. + Divinity & 0 & 0 & 3 & 2.1 & 1 & 2.7 & 4 & 1.6 \\
\hline B.A. + L.S. + D.L.S. & 0 & 0 & 19 & 13.1 & 2 & 5.4 & 21 & 8.4 \\
\hline $\begin{array}{l}\text { M.A. + L.S. + D.L.S. } \\
\text { Total }\end{array}$ & $\begin{array}{r}0 \\
68\end{array}$ & 0 & $\begin{array}{r}4 \\
145\end{array}$ & 2.8 & $\dot{1}$ & 2.7 & $\begin{array}{r}5 \\
250\end{array}$ & 2.0 \\
\hline
\end{tabular}

- All non-library science degrees are listed as B.A., M.A., and Ph.D. as appropriate. All library science master's and doctorates are listed as M.L.S. and D.L.S. respectively.

No degree information could be obtained for four individuals at time of being appointed to directorship.

M.L.S., and this was being reflected in ARL directors as well. The 1970-1973 period also showed some increases, notably in Ph.D. plus L.S. and B.A. + M.L.S. Notice that the four D.L.S. at entrance in 1934-1969 and the one in 1970-1973 have become twenty-three and three respectively by the time of becoming directors. Prior to 1968 , there were approximately 250 doctorates awarded in library science, while another 250 were awarded between 1969 and 1972 on the strength of federal monies. Yet the big increase in D.L.S. directors at ARL libraries is before the impact of that money, with a lower percentage of the incumbents having the D.L.S. ( 7.7 percent) for the period of 1970-1973 than for those (17.2 percent) in 1934-1969. Even more surprising, the incumbents show 12.2 percent with the D.L.S., while the overall group-including those in

\section{TABLE 4}

Degree (s) Held by 1973 Incumbents at Current Appointment (Blank Categories in Table 3 Are Omitted)

\begin{tabular}{lcrrrrr}
\hline \hline \multicolumn{1}{r}{ Name of Degree $(s)^{\circ}$} & 1934-1969 & Percent & 1970-1973 & Percent & Total & Percent \\
\hline B.A.+ M.A. & 1 & 2.9 & 1 & 2.6 & 2 & 2.7 \\
Ph.D. & 3 & 8.6 & 1 & 2.6 & 4 & 5.4 \\
B.L.S. only & 0 & 0 & 1 & 2.6 & 1 & 1.4 \\
B.A. + B.L.S. & 4 & 11.4 & 2 & 5.1 & 6 & 8.1 \\
B.A. + M.L.S. & 7 & 20.0 & 19 & 48.7 & 26 & 35.1 \\
M.A. + L.S. & 6 & 17.1 & 5 & 12.8 & 11 & 14.9 \\
Ph.D. + L.S. & 5 & 14.3 & 5 & 12.8 & 10 & 13.5 \\
B.A. + B.L.S. + M.L.S. & 1 & 2.9 & 1 & 2.6 & 2 & 2.7 \\
B.A. + L.S. + Divinity & 2 & 5.7 & 1 & 2.6 & 3 & 4.1 \\
B.A. + L.S. + D.L.S. & 5 & 14.3 & 3 & 7.7 & 8 & 10.8 \\
M.A. + L.S. + D.L.S. & 1 & 2.9 & 0 & 0 & 1 & 1.4 \\
$\quad$ Total & 35 & & 39 & & 74 & \\
\hline
\end{tabular}

- All non-library science degrees are listed as B.A., M.A., and Ph.D. as appropriate. All library science master's and doctorates are listed as M.L.S. and D.L.S. respectively. 
1933, when the degree had not yet been significantly awarded-show 10.4 percent. If the 1933 period is eliminated, the overall group for 1934-1973 shows over 14 percent with the D.L.S. Conclusion: Despite the increase in individuals with the D.L.S., the number of ARL directors with the degree is not increasing.

What of the Ph.D. degree? Formerly, 16.9 percent entered the field with the $\mathrm{Ph} . \mathrm{D}$., and 22 percent had it upon becoming director. The incumbents entered with 12.1 percent and became directors at 18.9 percent. Again, for those holding a doctorate outside of library science, the percentage of ARL directors has declined. Another 10.4 percent entered the profession overall with an M.A. plus library school, and this became 13.2 percent holding this combination by directing time. The incumbents entered with 10.8 percent and went on to 14.9 percent by appointment. More of the incumbents, percentage-wise, hold the outside master's degree plus library degree than did the overall group. The incumbents show their largest entry point as being B.A. + M.L.S. (31.1 percent), and this becomes 35.1 percent by appointment. The entire group only had 10.4 percent at entrance and 12.4 percent at appointment. Educationally, the incumbents show a much greater tendency to have the B.A. + M.L.S. and M.A. + M.L.S. than do their predecessors, but a significantly lowered tendency to have a doctorate in or out of the field.

Obviously, the incumbents are reflecting the current standards for the library professional in having the M.L.S. degree, while earlier directors were able to enter the field under a set of standards which did not offer (or at least did not insist upon) this degree. As the new standards were adopted, those already in the field were protected from the need for returning to obtain the M.L.S. by the weight of their experience and standing. It was to be expected that the professional practitioners would reflect the new degree for entrance to the profession, but it is surprising that the large increase in the numbers of librarians with doctorates is not being reflected in the ARL administrative pattern. It is altogether depressing that 30 percent of the incumbents were able to enter the field without a library degree and that 8 percent could become ARL directors without one. That is much better than the record of the group as a whole, but it still demonstrates a woeful lack of understanding on someone's part as to proper qualifications for directing a large academic research library.

\section{Age of DiRECtors}

If the expected increase in doctorate holders is not occurring, then what of the age difference at appointment? In this age of emphasis on youth, it was anticipated that the incumbents would be young doctors. Since they don't have the doctorate, do they show increasing youth at time of appointment? The answer, as seen in Tables 5 and 6 , is a resounding "No." They are entering the field younger, but they are being appointed as director at an older age than their predecessors.

Tables 5 and 6 do show very definite differences. With one exception, all of those appointed by 1933 had entered the field by forty-two and had been made a director between the age of twentyone and fifty-eight. Thirty-seven of the sixty-nine had made director by age forty. The directors for 1934-1969 also grouped entry in the period before age thirty, but thirteen entered after age forty-two. The appointment age, however, doesn't start until twenty-eight, and only sixty-one of the group had become directors by age forty versus sixtyseven who were appointed between forty-one and fifty, and twenty not appointed until in their fifties. By the 
TABLE 5

Age of Entry and Age of Apponntment for ARL Directors APPOINTED BY 1933, IN 1934-1969, AND IN 1970-1973

\begin{tabular}{ccccccc}
\hline \hline Age & \multicolumn{2}{c}{$\begin{array}{c}1933 \\
\text { Entry }\end{array}$} & Appointment & Entry & Appointment & \multicolumn{2}{c}{$1970-1973$} \\
Entry & Appointment \\
\hline $20-24$ & 22 & 3 & 41 & 0 & 7 & 0 \\
$25-29$ & 23 & 7 & 56 & 4 & 15 & 0 \\
$30-34$ & 14 & 13 & 22 & 21 & 9 & 1 \\
$35-39$ & 5 & 12 & 4 & 26 & 2 & 6 \\
$40-44$ & 2 & 9 & 11 & 50 & 2 & 10 \\
$45-49$ & 0 & 17 & 6 & 25 & 0 & 11 \\
$50-54$ & 1 & 7 & 1 & 13 & 0 & 1 \\
$55-59$ & 0 & 1 & 4 & 9 & 1 & 5 \\
$60-64$ & 0 & 0 & 0 & 0 & 1 & 2 \\
\hline
\end{tabular}

Twenty-one directors (ten current) are listed at appointment time of first two ARL directorships.

TABLE 6

Age of ENTry AND Age of Appointment FOR ARL INCUMBENTS

\begin{tabular}{crcrc}
\hline \hline Age & $\begin{array}{c}1934-1969 \\
\text { Entry }\end{array}$ & $\begin{array}{c}\text { 1970-1973 } \\
\text { ment }\end{array}$ & Entry & $\begin{array}{c}\text { Appoint- } \\
\text { ment }\end{array}$ \\
\hline $20-24$ & 9 & 0 & 6 & 0 \\
$25-29$ & 15 & 1 & 20 & 0 \\
$30-34$ & 8 & 4 & 13 & 1 \\
$35-39$ & 1 & 2 & 0 & 6 \\
$40-44$ & 0 & 10 & 1 & 11 \\
$45-49$ & 0 & 8 & 1 & 11 \\
$50-54$ & 0 & 4 & 0 & 4 \\
$55-59$ & 0 & 3 & 0 & 4 \\
$60-64$ & 0 & 0 & 0 & 2 \\
\hline
\end{tabular}

1970-1973 period, two-thirds had entered by age thirty and all but three by age forty. The appointment age, however, shows no one by age thirty, eight by forty, twenty by fifty, and nine over fifty-more appointed over the age of fifty than were by the age of forty.

The incumbents showed the acceleration of this trend to enter earlier and not become directors until later. Fiftythree had entered by the age of thirty, but only one was a director. Seventythree had entered by the age of forty, but still only seventeen had become directors. The last of the incumbents entered the field in his forties, the age at which forty of the incumbents became ARL directors. Another fourteen didn't gain appointment until over fifty-one, with two of those having passed sixty.
The range in professional experience before becoming director has jumped from a twelve-year span to a sixteenyear span in the years covered in this paper. The average entrance age has gone from twenty-eight in the 1930s to thirty-one in the 1970 s, while the incumbents averaged the same twenty-eight as their 1933 predecessors. The age of appointment, however, has gone from an average of thirty-nine in the 1930 s to the incumbent average of appointment at age forty-three-and-one-half. The ARL libraries are requiring more age (read experience) rather than more degrees for their leaders.

\section{Sex of Directors}

In addition to age and education, sex is often mentioned as a factor in academic administration. ARL libraries, unfortunately, do not refute the idea of male dominance unrelated to numbers in the profession. In 1933 there were fifteen women serving as directors at the ARL libraries. Between 1934 and 1969 , however, only two women were appointed to such directorships out of the 147 appointments made. During the period of 1970-1973, four women were appointed and are still serving. All were working at the library which appointed them at the time of promotion, and two were already in their sixties when chosen (the only two incumbents past 
sixty at appointment). Despite evidence from several researchers that mobility is a key factor in promotion within the profession, it would appear that women can only reach the top rungs by staying put and "proving" their abilities to those making the appointments. Further, it would appear that the increased size of the member libraries of ARL has led to a decreased number of female directors. It would be instructive to see how many women have reached the level below the director at these libraries and are, therefore, eligible to receive the next available promotion, but that is outside the scope of this study.

\section{Destinations of Departing DIRECTORS}

There are then some changes in background of those becoming directors, although much of it only reflects overall changes in the entire body of the professional practitioners. The M.L.S. is now the accepted degree, and there is an apparent decrease in starting age for librarians generally. As the starting positions have increased in number, creating more competition for higher assignments, it seems only natural that the need to present increased credentials would lead to increased age and/or experience in background. Similarly, as the ARL libraries become truly "big business," it is understandable that the powers that be would require an increased show of maturity. It can be ex- pected that both of these trends will continue as the current job market creates an increasingly competitive situation and a decreased chance for the mobility which leads to an easy upward movement.

If the background factors can thus be explained away as related to the background of the field generally, then how about the reasons so many appear to be "dropping out" of administration? A look at the destinations of those who have left ARL libraries over the years, compared with the destinations of those whose leaving made way for the incumbents, should indicate whether any sharp changes are happening (see Table 7).

The predecessors of incumbents left a little less because of death or retirement and because of a new position at a non-ARL library. More left for teaching and to direct a different ARL library. The predecessors for the 1970s, however, left for death and retirement slightly more often than the previous directors as a group, and they also went into teaching far more often than the group as a whole. Far less (in fact, none) went into a new library directorship at a non-ARL library. Conclusions: Roughly the same percentage of directors are leaving for death and retirement as in previous years, but teaching is becoming increasingly attractive to those who leave with career time still available. ARL libraries are looking

TABLE 7

Destinations of ARL Directors upon Leaving Position

\begin{tabular}{|c|c|c|c|c|c|c|c|}
\hline Period & Retired/Died & Teaching & $\begin{array}{c}\text { To Other } \\
\text { ARL Library }\end{array}$ & $\begin{array}{l}\text { To Other } \\
\text { Library }\end{array}$ & $\begin{array}{l}\text { Same Library, } \\
\text { New Position }\end{array}$ & Left Field & $\begin{array}{l}\text { Average Years } \\
\text { as Director }\end{array}$ \\
\hline \multicolumn{8}{|c|}{ All ARL directors } \\
\hline By 1933 & $52(78 \%)$ & $5(7 \%)$ & & $8(12 \%)$ & $2(3 \%)$ & & 23.5 \\
\hline $1934-1969$ & $45(34 \%)$ & $19(15 \%)$ & $14(11 \%)$ & $21(16 \%)$ & $2(2 \%)$ & $10(8 \%)$ & 12.65 \\
\hline 1970-1973 & $1(33 \%)$ & $2(67 \%)$ & 0 & 0 & 0 & & 2 \\
\hline Total & $98(54 \%)$ & $26(14 \%)$ & $14(8 \%)$ & $29(16 \%)$ & $4(2 \%)$ & $10(6 \%)$ & \\
\hline \multicolumn{8}{|c|}{ Incumbents' immediate predecessors } \\
\hline 1934-1969 & $15(39 \%)$ & $6(16 \%)$ & $9(24 \%)$ & $6(16 \%)$ & 0 & $2(5 \%)$ & 14.1 \\
\hline $1970-1973$ & $20(56 \%)$ & $9(25 \%)$ & $4(12 \%)$ & & 0 & $3(8 \%)$ & 15 \\
\hline Total & $35(47 \%)$ & $15(20 \%)$ & $13(18 \%)$ & $6(8 \%)$ & 0 & $5(7 \%)$ & 14.6 \\
\hline
\end{tabular}


closely at each other's directors, apparently on the theory that success at one ARL library should be a big boost toward success at another ARL institution. Non-ARL libraries are now uninterested or unable to attract any large numbers of ARL directors.

As to the teaching, there are far more teaching positions available now than formerly, and there is at least as strong a tendency toward requiring relevant experience in the area to be taught-i.e., the teaching of administration requires a former administrator. There is also the factor of an increasing number of schools requiring administrative retirement at an earlier age than teaching retirement, so the change may represent an attempt to stave off ending a career. Indeed, eight of the incumbents' predecessors went into teaching at rather advanced ages for a change of career aimed at any long-range future. Subtracting these from the teaching totals would reduce this category to below the percentage of total predecessors, while adding it to Retired/Died would send that total well over past performance.

It would appear that basically the same reasons are now accounting for the majority of departures from ARL directorships. Over one-half of the
ARL institutions appointed a director in the 1940s, usually immediately following World War II. Turnover on age grounds alone should have been expected, therefore, and should not be a reason for anxiety. It would appear that the replacements are a more experienced, but similarly educated group. The number without library-school training is diminishing too slowly, and the number of women is rising too slowly. Our leadership is changing names and faces, and coming a little slower to administration, but it is very close to the same persons updated to fit the new times. Conservatives have little cause for alarm, while those who feel some "real" change is needed are apparently in for disappointment. Unless some new trend develops, over half of the current ARL directors should still be in office fifteen years from now, and an increasing number of our library schools will be having administration taught by former ARL directors. That may be for the good or for the bad, but it is unlikely to cause any major changes anytime soon. Whatever may be happening in ARL-level administration, it is happening with the same type of individuals it has always used, and this will probably continue to be the case. 